\title{
Failure to maintain interspecific pregnancy after transfer of Dall's sheep embryos to domestic ewes
}

\author{
B. C. Buckrell†, C. J. Gartley†, K. G. Mehren*, G. J. Crawshaw*, \\ W. H. Johnson†, I. K. Barkerț, J. Balke§, C. Coghill*, J. R. G. Challis $\uparrow$ and \\ K. L. Goodrowe* \\ Departments of $\dagger$ Population Medicine and $\ddagger$ Pathology, Ontario Veterinary College, University of \\ Guelph, Guelph, Ontario, Canada NIG 2WI; *Metropolitan Toronto Zoo, West Hill, Ontario, \\ Canada MIE 4R5; §St Louis Zoo, St Louis, Missouri, USA; and $\$$ Lawson Research Institute, \\ University of Western Ontario, London, Ontario, Canada N6A $4 \mathrm{~V} 2$
}

\begin{abstract}
Summary. Over a 3-year period, 32 Dall's sheep (Ovis dalli dalli) embryos were transferred into 24 domestic sheep (O. aries) recipients and 4 were transferred into 2 Dall's sheep recipients. In the first year, none of the $10 \mathrm{O}$. aries recipients was diagnosed pregnant. In the following 2 years, $9(37 \%)$ of the domestic sheep recipients were pregnant on Day 18, $8(33 \%)$ on Day $40,6(25 \%)$ on Day 90 and $4(16 \%)$ on Day $120 ; 1$ aborted at Day 125 and another at Day 145. Pregnancies were established only in ewes that had previously been recipients of Dall's sheep embryos. The 2 remaining pregnant sheep were treated with progesterone from Day 125 until the fetuses were determined to be dead at Day 145. Both of the Dall's sheep recipients (Year 2) established pregnancies; 1 live Dall's sheep lamb was born 174 days after mating. No differences in serum progesterone, oestrone, prostaglandin F-2 $\alpha$ metabolites or cortisol concentrations could be detected during pregnancy between recipients carrying Dall's sheep embryos, recipients receiving progesterone treatment or domestic ewes carrying domestic sheep pregnancies. Six fetuses were necropsied (1 at Day 125 and 5 at Day 145-146): all fetuses were premature and had various degrees of hydranencephaly. No significant differences were found when cotyledon numbers were compared among domestic ewes carrying Dall's sheep lambs, Dall's sheep ewes lambing naturally and domestic ewes lambing naturally. These results demonstrate that the transfer of Dall's sheep embryos to domestic ewes results in the establishment but subsequent loss of pregnancy and that these losses occur throughout gestation.
\end{abstract}

Keywords: sheep; embryo transfer; interspecies; pregnancy failure; superovulation

\section{Introduction}

Dall's sheep (Ovis dalli dalli, $2 \mathrm{n}=54$ ), a species indigenous to the Canadian Northwest and Alaska, is seasonally polyoestrous (K. L. Goodrowe, personal observation) with mating occurring in the fall months and lambing in the spring. Gestation has been estimated at 170-175 days from peak rutting to peak lambing (Nichols, 1978). At the Metropolitan Toronto Zoo (MTZ) successful rearing of Dall's sheep lambs has proved to be difficult. While a large proportion of the flock $(\mathrm{N}=$ 22 in 1984) lamb successfully, survival to weaning is poor (average $51 \cdot 5 \%$, range $11-78 \%$, from 1976 to 1986) due predominantly to $E$. coli septicaemia and diarrhoea of undetermined aetiology. There is evidence that poor transfer of colostral immunoglobulin from Dall's sheep ewes to their lambs may be a contributing factor (G. J. Crawshaw, personal communication). 
In the light of these difficulties, an embryo transfer project was initiated to determine whether Dall's sheep embryos would develop normally in domestic ewes. Using superovulation techniques, it was expected that an increased number of lambs could be produced and that domestic recipients would provide better colostral transfer of immunoglobulin and an improved social development for the neonate. Because there was no information available regarding hormonal changes during pregnancy in Dall's sheep or interspecific embryo transfers, the endocrine events of intra- and interspecific pregnancies were monitored.

Although both the Dall's sheep and domestic sheep ( $O$. aries) are classified within the genus $O$ vis they are grouped into separate subgenera. Hybridization and embryo transfer have been successfully completed between species within the subgenus that includes the domestic sheep (mouflon to domestic sheep) (Bunch et al., 1977), but no reports exist of embryo transfer between the two subgenera. However, hybridization has been documented between a 'mountain sheep' ram and Lincoln-Cotswold ewes in Alaska in 1934 (Palmer, 1934). Several reports exist of hybridization of bighorn sheep (O. canadensis) with domestic sheep (Pillmore \& Teague, 1955; Young \& Manville, 1960) and Desert bighorn sheep (O. canadensis nelsoni) crossed with $O$. aries (Pulling, 1945). In addition, reports of successful interspecific embryo transfer within the Families Bovidae (bongo and eland, gaur and Holstein cattle) (Stover et al., 1981; Dresser et al., 1984) and Equidae (donkey and horse, zebra to horse) (Allen et al., 1985; Bennet \& Foster, 1985) and hybridization between Barbary sheep and domestic goats (Moore et al., 1981) supported the decision to attempt this procedure between Dall's sheep and domestic sheep. Of greatest concern was the estimated difference of almost 3 weeks in gestation length. However, previous reports of the fetal contribution to the timing of parturition in domestic sheep indicate that the fetus is responsible for initiating parturition, suggesting that the discrepancy in gestation lengths between these two sheep species should not pose a problem for interspecific pregnancy maintenance (Bradford et al., 1972; Anderson et al., 1981).

\section{Materials and Methods}

Synchronization of oestrus and superovulation. In Year 1 (1984) 6 Dall's sheep ewes were used as embryo donors for 8 flushes and 10 Polled Dorsets were used as recipients. In Year 2 (1985), 6 Dall's sheep donors were used for 7 flushes; 8 Polled Dorsets and 2 Dall's sheep were used as recipients. In Year 3 (1986), 4 Dall's sheep were used, once each as donors, and 6 Polled Dorsets were used as recipients. All Dall's sheep were mature, multiparous ewes of various ages; all Dorsets were healthy nulliparous yearlings in the first year of the programme. All transfers were performed during the rutting period (October to December). Donors and recipients were synchronized with vaginal pessaries impregnated with $60 \mathrm{mg}$ medroxyprogesterone acetate (MAP) (Veramix Sheep Sponges: Tuco Products Co., Division of Upjohn, Orangeville, Ont., Canada) which were removed after 14 days. The first 4 embryo donors were superovulated using a single intramuscular (i.m.) injection of 1200 i.u. pregnant mares' serum gonadotrophin (PMSG) (Equinex: Ayerst Laboratories, Montréal, Québec, Canada) given $48 \mathrm{~h}$ before pessary removal. The remaining donors in Year 1 and all donors in Years 2 and 3 were superovulated using $20 \mathrm{mg}$ follicle-stimulating hormone (FSH) (FSH-P: Schering Canada Inc., Pointe Claire, Québec, Canada) divided into 6 doses $(5,4,4,3,2,2 \mathrm{mg})$ injected i.m. every $12 \mathrm{~h}$, beginning $48 \mathrm{~h}$ before sponge withdrawal. The vaginal pessaries were removed at the time of the fifth injection. A Dall's sheep ram was introduced to the donor ewes $24 \mathrm{~h}$ after sponge removal and remained for $48 \mathrm{~h}$. All recipient ewes received 500 i.u. PMSG at the time of pessary removal.

Embryo collection. Seven days after pessary removal, the donor ewes, having been fasted for 24 h, were anaesthetized with $250 \mathrm{mg}$ ketamine (Ketamine HCl: Parke Davis, London, Ont., Canada) and $50 \mathrm{mg} x y l a z i n e$ (Rompun: Haver, Bayvet Division, Chemagro Ltd, Etobicoke, Ont., Canada) administered together intravenously, intubated and brought to the surgical facilities at the MTZ. The ewes were maintained under halothane anaesthesia and prepared for a ventral mid-line coeliotomy. An antegrade uterine flushing technique was used (Gartley, 1989). After surgery each donor ewe received $125 \mu \mathrm{g}$ cloprostenol (Estrumate: Coopers Agropharm Inc., Willowdale, Ont., Canada) to induce luteolysis.

Embryo handling. Embryos were held in filtered (Millex-GV, 0.22 $\mu \mathrm{m}$ Filter Unit: Millipore Corporation, Bedford, MA, USA) phosphate-buffered saline (Dulbecco's Phosphate Buffered Saline: Gibco Laboratories, Life Technologies Inc., Grand Island, NY, USA) supplemented with 10\% ovine serum (Fresh Ovine Serum, Woodlyn Laboratories, Guelph, Ontario, Canada) and antibiotic-antimycotic (Antibiotic-Antimycotic Solution, Gibco Laboratories, Life Technoloies Inc., Grand Island, NY, USA) at $37^{\circ} \mathrm{C}$ until transfer. Time from collection until transfer varied but was 
rarely less than $2 \mathrm{~h}$ and never more than $4 \mathrm{~h}$. During the holding period embryos were assessed for developmental stage and embryo quality using previously described techniques (Kuzan, 1984).

Embryo transfer. The domestic embryo recipients chosen were purebred Polled Dorsets $(O$ aries, $2 \mathrm{n}=54)$ with an average gestation of 144-146 days. Recipient ewes were sedated with $15 \mathrm{mg}$ xylazine given i.m. and prepared for a ventral midline incision similar to that of the donors. The incision site was infiltrated with $15 \mathrm{ml}$ lidocaine (Lidocaine HCl 2\%: Armitage Carroll, Guelph, Ont., Canada) for local analgesia. Embryos were deposited into the exposed uterine horn ipsilateral to a corpus luteum: 1 or 2 embryos were deposited, but in all cases embryos were transferred into only I horn.

Pregnancy diagnosis. The pregnancy status of each recipient ewe was assessed 18,40,90 and 120 days after oestrus. The Day- 18 pregnancy status was based on serum progesterone concentrations as determined by previously validated RIA methods for sheep (Kendall et al., 1977; Glickman et al., 1979; Challis et al., 1981). The antiserum (ICI Ltd, Macclesfield, Cheshire, UK) had cross-reactivities of: $35.9 \%$ with 4-pregnen-11 $\alpha$-ol-3,20 dione, $23.8 \%$ with deoxycorticosterone, $3.4 \%$ with 4-pregnen-11 1 -ol-3,20 dione, and $<1 \%$ with other pregnane, oestrane and androstane steroids. The solvent blank was not significantly different from zero and was not deducted. The recovery of progesterone added to Krebs--Ringer solution at concentrations between 0.125 and $1.0 \mathrm{ng} / \mathrm{ml}$ was $y=0.001+1.03 x$, where $y$ was the amount of progesterone recovered and $x$ was the amount of progesterone added. The intra-assay coefficient of variation $(\mathrm{CV})$ over this concentration range was $12.5 \%$ and the interassay $\mathrm{CV}$ was $13.6 \%$. The antiserum was further evaluated by determining the progesterone in samples directly after extraction with petroleum ether (b.p. $40-60^{\circ} \mathrm{C}$ : Fisher Chemicals) or after extraction and purification using microcelite chromatography. Methodological losses were corrected by measuring the recovery of 1000 d.p.m. purified $\left[{ }^{3} \mathrm{H}\right]$ progesterone (New England Nuclear, Boston, MA, USA; sp. act. $90-115 \mathrm{Ci} / \mathrm{mmol}$ ) added to each sample before extraction. Ewes with a serum progesterone concentration of less than $1 \mathrm{ng} / \mathrm{ml}$ were considered to be not pregnant. Rectal and flank real-time ultrasound $(5 \mathrm{MHz})$ were used for pregnancy diagnosis at the later stages (Buckrell et al., 1986; Buckrell, 1988).

Progesterone treatment during pregnancy. In Year 3, 2 Dorset recipients at 125 days of gestation were treated with $5 \mathrm{mg}$ repositol progesterone (Centra Progestin: Central Sales Ltd, Brampton, Ont., Canada) i.m. every 5th day until the termination of the live pregnancies. These pregnancies were monitored twice weekly using real-time ultrasound (Buckrell, 1988).

Necropsies. Necropsies were conducted on 4 Dorset recipient ewes (1 from Year 2 and 3 from Year 3 ) and 6 Dall's sheep lambs being carried by the necropsied Dorset recipients. Uterine, placental and fetal tissues were submitted for histology. Bacterial and chlamydial cultures and serology for Coxiella burnetii were also submitted. Fetal crown-rump lengths and weights, placental weights and placentome numbers were recorded.

Cotyledon counts. The number of cotyledons was recorded from each Dall's sheep lamb placenta, whether twin or singleton, at the time of necropsy. For purposes of comparison, counts were made from 9 Dall's sheep placentas delivered naturally and 5 Dorset ewes carrying Dorset pregnancies at the MTZ. Mean cotyledon numbers were compared using Student's $t$ test and ANOVA. Cotyledon and placental weights were not compared.

\section{Results}

\section{Superovulation, embryo recovery and transfer}

The 4 Dall's sheep ewes superovulated with PMSG produced corpora lutea (Table 1). However, each ewe experienced unovulated follicles and distension of periovarian tissues with oedema. While ova/embryos were recovered from these ewes, most were unfertilized leaving only 2 for transfer. Using FSH, yield from the 4 donor ewes was: 10 transferable embryos from 13 recovered (77\%) in Year 1, 12 transferable embryos of 15 collected (80\%) in Year 2, and 12 of $15(80 \%)$ in Year 3. Of the 36 embryos transferred (Table 1), 30 were morulae, 2 were hatched blastocysts and 4 were retarded in development. All morulae and blastocysts recovered were transferred. Only unfertilized ova and empty zonae were discarded.

\section{Pregnancies}

In Year 1, of the 27 embryos collected, 12 were transferred to 10 recipients. No pregnancies were diagnosed (Table 2). In Year 2, 12 embryos were transferred into 10 recipients (8 Dorsets and 2 Dall's sheep). Both Dall's sheep recipients were pregnant at Day 18 but by Day 40 only one pregnancy could be imaged. That ewe gave birth to a live, normal Dall's sheep lamb at 174 days after the donor's breeding date. Of the 8 domestic sheep recipients only 2 were pregnant at Day 90 
Table 1. Ovarian responses to two superovulatory gonadotrophin regimens in Dall's sheep (Ovis dalli dalli) and results of subsequent embryo transfer to domestic ewes $(O$.aries)

\begin{tabular}{lcccccccc}
\hline Treatment & $\begin{array}{c}\text { No. of } \\
\text { sheep }\end{array}$ & $\begin{array}{c}\text { Corpora } \\
\text { lutea } \\
(\text { mean })\end{array}$ & $\begin{array}{c}\text { Unovulated } \\
\text { follicles } \\
(\text { mean })\end{array}$ & $\begin{array}{c}\text { Embryos } \\
\text { recovered } \\
(\%)^{*}\end{array}$ & $\begin{array}{c}\text { Ova/ } \\
\text { discarded } \\
(\%)^{\dagger}\end{array}$ & $\begin{array}{c}\text { Unfertilized } \\
\text { ova } \\
(\%) \dagger\end{array}$ & $\begin{array}{c}\text { Embryos } \\
\text { transferred } \\
(\%)^{\dagger}\end{array}$ & $\begin{array}{c}\text { Ewes } \\
\text { pregnant } \\
(\%)_{+}^{+}\end{array}$ \\
\hline PMSG & 4 & $24(6)$ & $11(2 \cdot 75)$ & $14(58)$ & $12(86)$ & $12(86)$ & $2(14)$ & 0 \\
FSH & 15 & $67(4 \cdot 6)$ & $5(2 \cdot 0)$ & $43(64)$ & $9(21)$ & $6(14)$ & $34(79)$ & $9(37)$ \\
\hline
\end{tabular}

*As $\%$ of corpora lutea.

$\uparrow$ As \% of embryos recovered.

$\ddagger$ Day-18 pregnancies established.

(Table 2). Within a week of the 90-day pregnancy check 1 of the recipients appeared as though she had aborted, having a bloody, moist perineal region and an engorged mammary gland but no fetus or placental tissues were found. Ultrasound and abdominal radiography revealed that no conceptus was present. The sole remaining pregnant recipient developed an enlarged, engorged mammary gland about Day 140 of gestation; at Day 145 she aborted a dead, underdeveloped fetus. In Year 3, 12 embryos were transferred into Dorset recipients ( 2 per recipient): 3 were pregnant at Day 120 $(50 \%)$. At Day 125 , one of these ewes aborted. The remaining 2 pregnant sheep were given supplementary progesterone treatment. At Day 144, indicators of fetal viability (fetal movement and heart beat) could not be found in one of the ewes. By the next morning the fetal heart beat could not be imaged in the other recipient ewe. Both ewes were noted to have fully developed mammary glands and enlarged teats filled with colostrum. Both ewes were killed and the reproductive tracts were immediately recovered: both had twin lamb pregnancies.

Table 2. Chronological distribution of Dall's sheep (Ovis dalli dalli) pregnancy losses in domestic sheep (O. aries)

\begin{tabular}{|c|c|c|c|c|c|c|c|}
\hline \multirow[b]{2}{*}{ Year } & \multirow{2}{*}{$\begin{array}{l}\text { Embryos } \\
\text { transferred }\end{array}$} & \multirow{2}{*}{$\begin{array}{l}\text { No. of } \\
\text { recipients }\end{array}$} & \multicolumn{3}{|c|}{$\begin{array}{l}\text { Pregnancy tested positive } \\
\qquad(\%)\end{array}$} & \multicolumn{2}{|c|}{$\begin{array}{c}\text { Observed } \\
\text { pregnancy failure }\end{array}$} \\
\hline & & & Day 18 & Day 40 & Day 90 & Day 125 & Day 145 \\
\hline 1 & 12 & 10 & - & - & - & - & - \\
\hline 2 & 8 & 8 & $4(50)$ & $3(37)$ & $2(25)$ & - & 1 \\
\hline 3 & 12 & 6 & $5(83)$ & $5(83)$ & $4(66)$ & 1 & $2^{*}$ \\
\hline Total & 32 & 24 & $9(37)$ & $8(33)$ & $6(25)$ & I & 3 \\
\hline
\end{tabular}

*Sheep treated with progesterone.

\section{Necropsies}

Of the recipients that lost their pregnancies, 4 were autopsied ( 1 at Day 125, 1 at Day 145 and the 2 at Day 146). The mammary enlargement and colostrum-like milk seen in these ewes was exactly as one would expect at term. The teats were characteristic of full-term gestation. No abnormal findings were noted from any ewe. Uterine cultures for aerobic bacteria and chlamydia and serology for Coxiella burnetii were negative. The placentas appeared normal and seemed to be of normal weight and size ( 1 Day-125 placenta at $106 \mathrm{~g}$, and 5 Day-145 placentas averaging $290 \mathrm{~g}$ ) for the species. The number of cotyledons was $49 \cdot 4 \pm 4 \cdot 1$ per lamb.

A total of 6 fetuses were available for autopsy: 1 at 125 days (195 $\mathrm{g}$ and crown-rump length $20 \mathrm{~cm}$ ), 1 at 145 days (weight not available, crown-rump length $30 \mathrm{~cm}$ ) and 2 sets of twins (averaging $592 \mathrm{~g}$ and $25 \mathrm{~cm}$ ) from the 2 ewes killed at Day 146. All fetuses showed varied degrees of 
autolysis but none was macerated. A lamb from 1 of the sets of twins showed evidence of very recent death while the other had been dead for 1 day or more. Based on hair development, each of the late-term fetuses was estimated to be at least 3 weeks from term. Each fetus was noted to have a variable degree of hydranencephaly and equivocal brachygnathia superior. Mineralization was noted in various locations in the cerebrum and the cerebellum. The cause(s) for the anomalies and the fetal deaths was not determined.

\section{Cotyledons}

The placentas of the Dall's sheep lambs carried in the Dorset ewes averaged $49 \cdot 4 \pm 4 \cdot 1$ cotyledons, the Dall's sheep lambs $53.3 \pm 3.5$ and the Polled Dorset lambs $61.8 \pm 4.7$. These cotyledon counts do not differ significantly.

\section{Endocrinology}

Endocrine profiles throughout pregnancy in Dorset ewes carrying Dorset lambs were compared with those of Dorset ewes carrying Dall's sheep fetuses and this latter group was further divided into the two ewes which aborted before Day 125 and the 2 ewes which were treated with progesterone. No obvious differences between progesterone, oestrone, PGFM and cortisol concentrations could be found during pregnancy in the three groups and statistical analysis was not done due to small sample size.

\section{Discussion}

The high incidence of unovulated follicles, retention of fluid in the periovarian tissues and unfertilized oocytes in conjunction with low rates of ova recovery in Dall's sheep following the use of a single PMSG injection were similar to observations reported for domestic and wild sheep (Bunch et al., 1977; Smith, 1988). While the embryo recovery rate in this case was acceptable $(58 \%)$, and the possibility of a ram effect on fertilization cannot be ruled out, the low fertilization rate $(14 \%)$ suggested that an alternative superovulation regimen was required. Results from FSH treatment were more acceptable, but remained below those obtained in a commercial sheep embryo transfer programme with sheep of several different breeds being conducted concurrently (Buckrell et al., 1989); 4.6 ovulations per Dall's sheep donor compared to 18.6 in the commercial programme. However, the recovery rates were similar (64\% compared to $78 \%$ in the commercial programme), as was the proportion of recovered embryos of transferable quality ( $79 \%$ compared to $69 \%$ for the commercial programme). Decreased embryo recovery and embryo quality has also been observed in non-domestic bovids, such as the scimitar-horned oryx and bongo, when compared to domestic cattle (Schiewe et al., 1988). Combined, these data suggest that alternative superovulation regimens for non-domestic bovids and ovids may be necessary to achieve desirable embryo collection results.

The failure to establish interspecific pregnancies in the first year of the project cannot be explained. Because of these early failures, the control transfers of Dall's sheep embryos to Dall's sheep recipients were made in Year 2. The initial pregnancy rate of $100 \%$ (2 of 2) at Day 18 with the eventual birth of the single live Dall lamb established our ability to perform the transfers successfully under the MTZ conditions and confirmed previous approximations of a 174-day gestation length for the Dall's sheep.

The failures of the 9 established interspecific pregnancies during Years 2 and 3 were evenly distributed throughout gestation. Possible causes include immunological failure or rejection, insufficient endocrine 'communications' between the Dall's sheep fetus, the placenta and the dam, incompatibilities between endometrial and placental growth factors and receptors in these species, and teratogens that might have contributed to or caused the hydranencephaly. 
Hypotheses for immunological causes of failed interspecific and intraspecific pregnancies have been proposed but remain unsubstantiated. Failures of early sheep goat hybrid pregnancies were explained as an immunological rejection as evidenced histologically by the infiltration of large numbers of leucocytes into the placenta and uterus (Dent et al., 1971; McGovern, 1973). Using an interspecific pregnancy model in the mouse, Clark et al.(1986) suggested that pregnancy failure was due to lack of trophoblastic stimulation at the decidua with subsequent fetal death due to failure of suppression of maternal cytotoxic lymphocyte activation. An immunological hypothesis for failure of interspecific pregnancies has been considered for equids (Allen et al., 1985) in which fetal genotype influences endometrial cup development and production of chorionic gonadotrophin. Allen et al. (1985) demonstrated that prior immunization of mares carrying donkey embryos, either passively with sera from pregnant mares or actively with paternal donkey lymphocytes, improved the success rate substantially. Selected cases of women experiencing habitual abortions have been successfully treated by immunizing the patient with paternal antigens (Gill, 1988), the possibility being that maternal cytotoxic factors are actively suppressed by trophoblastic antigens of paternal origin in order for the pregnancy to survive. Others (Croy et al., 1985) have found that immunization of recipients in the mouse interspecific model resulted in more rapid embryo resorption. However, when immune-mediated failures have been suspected, most pregnancies are reported lost in the first half of gestation (McGovern, 1973; Allen et al., 1985; Clark et al., 1986), unlike in this study, in which the losses occurred throughout gestation.

In this study, the 4 interspecific pregnancies which survived to late term ( 125 days and beyond) were established in ewes that had previously received Dall's sheep embryos. No pregnancies were established the first year of the programme in ewes that had never received a Dall embryo previously. This finding is contrary to the experiences of other investigators (goat in sheep: McGovern, 1973; donkey in horse: Allen et al., 1985) who showed a decreased, not increased, time to pregnancy rejection in recipients in subsequent interspecific pregnancies, perhaps due to 'immune memory'.

Factors responsible for the maintenance of pregnancy and parturition vary in animals of different genera. The Barbary sheep (Ammotragus lervia, $2 \mathrm{n}=58$ ) closely resembles the sheep in the endocrine regulation of pregnancy (Flint $e t$ al., 1983). Because sheep and goats have descended from a common rupicaprid ancestor (Porter et al., 1982), it is possible that the endocrine regulation of Dall's sheep pregnancy may resemble that of the goat rather than the sheep. If Dall's sheep were different from domestic sheep the chance for normal fetal development and parturition would be reduced.

Placental histology has been used to explain the successful embryo transfer between the bongo and eland antelopes, whereas the large differences found between placentas of the giraffe and okapi predict a poor outcome (Hradecky et al., 1987). Failures of interspecific embryo transfer of the gaur (Bos gaurus) to Holstein cattle (Bos taurus) were believed to result from placental insufficiency caused by a reduced number of placentomes and failure of normal apposition of the crypts and villi (Hradecky et al., 1988). In donkey-in-mare pregnancies, donkey chorionic girdle cells fail to invade the horse endometrium and do not produce normal endometrial cups; the chorio-allantois therefore cannot firmly attach to the endometrium (Allen et al., 1985). Placental incompatibility and the number and size of placentomes probably contributes to the failure of placental transfer/production of pregnancy-specific hormones and nutrients (Caton et al., 1984).

In sharp contrast to the premature delivery noted in this study, fetal anencephaly caused by Veratrum californicum poisoning in pregnant sheep results in prolonged gestation (Jubb \& Kennedy, 1986). Furthermore, placental insufficiency resulted in retarded development of the fetuses with one stillborn at term and one going well beyond normal term ( 308 days) when gaur embryos were transferred to Holstein cows (Hradecky et al., 1988). Information is not available to permit a comparison of the fetal weights obtained in this study with those of the normal Dall's sheep fetus.

We have shown that Dall's sheep embryos will establish pregnancy at Day 18 in domestic ewes, up to a rate of $83 \%$. The prior transfer of Dall's sheep embryos to those recipients may have been a 
factor in those successes. Unfortunately, those recipients have been lost from the programme and the hypothesis cannot be tested. That the Dall's sheep may be similar to the goat or unique in factors regulating its pregnancy remains a possibility. In 1987, 4 Dall's sheep embryos were transferred to 2 goat recipients; one established a pregnancy which was lost between the Day-60 and Day-90 ultrasound imaging.

Interspecific pregnancy failure may only be one directional. Croy et al. (1985) have demonstrated a similar phenomenon with interspecific mouse pregnancies as have others working on hybridization between sheep and goats (McGovern, 1973) and between donkey and horse (Allen $e t$ al., 1985). With a zoo species in limited supply, it is inappropriate to produce hybrids, and therefore no attempts were made to transfer domestic sheep into the Dall's sheep recipients or to hybridize the two species. However, it would of further interest to pursue other recipient species, such as the Bighorn sheep, the Barbary sheep or mouflon while concomitantly placing emphasis on basic physiological studies in this species.

We thank Dr B. A. Croy for comments and the keepers at the MTZ for technical assistance. This work was funded in part by the Blackstock Fellowship of the Metropolitan Zoological Society.

\section{References}

Allen, W.R., Kydd, J.H., Boyle, M.S. \& Antczak, D.F. (1985) Between species transfer of horse and donkey embryos: a valuable research tool. Equine vet. $J$. Suppl. 3, 53-62.

Anderson, G.B., Bradford, G.E \& Cupps, P.T. (1981) Length of gestation in ewes carrying lambs of two different breeds. Theriogenology 16, 119-129.

Bennet, S.D. \& Foster, W.R. (1985) Successful transfer of zebra embryo to a domestic horse. Equine vet. J., Suppl. 3, 78-79.

Bradford, G.E., Hart, R., Quirke, J.F. \& Land, R.B. (1972) Genetic control of the duration of gestation in sheep. J. Reprod. Fert. 30, 459-463.

Buckrell, B.C. (1988) Applications of ultrasonography in reproduction in sheep and goats. Theriogenology 29, $71 \cdots 84$.

Buckrell, B.C., Bonnett, B.N. \& Johnson, W.H. (1986) The use of real-time ultrasound rectally for early pregnancy diagnosis in sheep. Theriogenology 25, $665-673$.

Buckrell, B.C., Gartley, C.J. \& Johnson, W.H. (1989) Results of a commercial sheep embryo transfer program. Theriogenology 31, 178, abstr.

Bunch, T.D., Foote, W.C. \& Whitaker, B. (1977) Interspecies ovum transfer to propagate wild sheep. $J$. Wldl. Mgmt 4, 726-730.

Caton, D., Bazer, F.W., Kalra, P.S. \& Moffatt, R.J. (1984) Adaptations to reduction of endometrial surface available for placental development in sheep. $J$. Reprod. Fert. 72, 357-364.

Challis, J.R.G., Patrick, J.E., Cross, J., Workewych, J., Manchester, E. \& Power, S. (1981) Short-term fluctuations in the concentration of cortisol and progesterone in fetal maternal plasma and amniotic and allantoic fluids from sheep during late pregnancy. Can. J. Physiol. Pharmacol. 59, 261-267.

Clark, D.A., Croy, B.A., Rossant, J. \& Chaouat, G. (1986) Immune presensitization and local intrauterine defences as determinants of success or failure in murine interspecies pregnancies. $J$. Reprod. Fert. $77,633-643$.
Croy, B.A., Rossant, J. \& Clark, D.A. (1985) Effects of alterations in the immunocompetent status of $M u s$ musculus females on the survival of transferred Mus caroli embryos. J. Reprod. Fert. 74, 479489.

Dent, J., McGovern, P.T. \& Hancock, J.L. (1971) Immunological implications of ultrastructural findings of goat $\times$ sheep hybrid placentae. Nature, Lond. 231, 116-117.

Dresser, B.L., Pope, C.E., Kraemer, L., Kuehn, G., Dahlhausen, R.D., Maruska, E.J., Reece, B. \& Thomas, W.D. (1984) Nonsurgical embryo recovery and successful interspecies embryo transfer from Bongo (Tragelaphus euryceros) to Eland (Tragelaphus oryx). Proc. A. Am. Ass. Zoo Vet. Mig, p. 180.

Flint, A.P.F., Burton, R.D. \& Heap, R.B. (1983) Sources of progesterone during gestation in Barbary sheep (Ammotragus lervia). J. Endocr. 98, 283-288.

Gartley, C.J. (1989) Lamb production using embryo transfer, bisection, cryopreservation and cryopreservation/ bisection. D.V.Sc. thesis, University of Guelph.

Gill, T.J., III (1988) Immunology and genetic factors influencing pregnancy. In The Physiology of Reproduction, Vol. 2, pp. 2032-2033. Eds E. Knobil \& J. D. Neill. Raven Press, New York.

Glickman, J.A., Carson, G.D. \& Challis, J.R.G. (1979) Differential effects of synthetic adrenocorticotrophin ${ }^{1-24}$ and $\alpha$-melanocyte-stimulating hormone on adrenal function in human and sheep fetuses. Endocrinology 104, 34-39.

Hradecky, P., Benirschke, K. \& Stott, G.G. (1987) Implications of placental structure compatibility for interspecies embryo transfer. Theriogenology $\mathbf{2 8}$, 737-745.

Hradecky, P., Stover, J. \& Stott, G.G. (1988) Histology of heifer placentome after interspecies transfer of a gaur embryo. Theriogenology 30, 593-605.

Jubb, K.V. \& Kennedy, P.C. (1986) Pathology of Domestic Animals, 3rd edn, pp. 203-205. Academic Press, New York.

Kendall, J.Z., Challis, J.R.G., Hart, I.C., Jones, D.T., Mitchell, M.D., Ritchie, J.W.K., Robinson, J.S. \& Downloaded from Bioscientifica.com at 04/26/2023 06:03:16AM via free access 
Thorburn, G.D. (1977) Steroid and prostaglandin concentrations in the plasma of pregnant ewes during infusion of adrenocorticotrophin or dexamethasone to intact or hypophysectomized foetuses. J. Endocr. 75, 59-71.

Kuzan, F. (1984) Classification of embryos prior to freezing. In Techniques for Freezing Mammalian Embryos (1984 Short Course Proceedings), pp. 39-50. Ed. R. P. Elsden. Animal Reproduction Laboratory, Colorado State University, Colorado.

McGovern, P.T. (1973) The effect of maternal immunity on the survival of goat $\times$ sheep hybrid embryos. $J$. Reprod. Fert. 34, 215-220.

Moore, N.W., Halnan, C.R.E., McKee, J.J. \& Watson, J.I. (1981) Studies on hybridization between a Barbary ram (Ammotragus lervia) and domestic ewes (Ovis aries) and nanny goats (Capra hircus). $J$. Reprod. Fert. 61, 79-82.

Nichols, L. (1978) Dall sheep reproduction. J. Wildl. Mgmt 3, 570-580.

Palmer, L.J. (1934) Statement of initiation of mountain sheep breeding investigations in Alaska. Alaska Agric. Exp. Stn, Progress Report, pp. 30-36.
Pillmore, R.E. \& Teague, R.D. (1955) Hybrid historybighorn cross. Colo. Conserv. 4, 22-26. [Biol. Abstr. 30, No. 1873 (1956).]

Porter, D.G., Heap, R.B. \& Flint, A.P.F. (1982) Endocrinology of the placenta and the evolution of viviparity. J. Reprod. Fert., Suppl. 31, 113-138.

Schiewe, M.C., Bush, M., Phillips, L.G. \& Wildt, D.E. (1988) Variables influencing the collection and cryopreservation of embryos from nondomestic hoofed species. Proc. 11th Int. Congr. Anim. Reprod. \& A.I., Dublin 2, 190.

Smith, L.C. (1988) Superovulation in sheep. Comp. Cont. Ed. Prac. Vet. 10, 1415-1423.

Stover, J., Evans, J. \& Dolensek, E.P. (1981) Interspecies embryo transfer from the gaur to domestic Holstein Proc. Annual Amer. Assoc. Zoo Vet. Mtg., Seatle, pp. 122-124.

Young, S.P. \& Manville, R.H. (1960) Records of bighorn hybrids. J. Mammal. 41, 523-525.

Received 2 January 1990 